\title{
Green roof substrates: Effect of recycled crushed porcelain and foamed glass on plant
} growth and water retention

(1)

\section{Abstract}

A study was conducted in a controlled environment greenhouse to examine the potential of recycled crushed porcelain and foamed glass for use as a component of green roof substrates. Porcelain and foamed glass substrates were compared to heat-expanded shale which served as the control. Each finished substrate was analyzed per German FLL guidelines to determine granulometric distribution, bulk density, total porosity, water-holding capacity, saturated hydraulic conductivity, $\mathrm{pH}$, soluble salts, organic matter content, and cation exchange capacity. Both substrates met FLL Guidelines except the porcelain substrate contained a greater percentage of larger particles and its maximum water holding capacity was lower than recommended. Two plant species were used in the study, Sedum album (stonecrop) and Ocinum x citriodolum (lemon basil). Data collected included substrate volumetric moisture content (VMC), plant growth, biomass accumulation, and plant stress as measured by chlorophyll fluorescence. Substrate VMC was generally greater in shale than in foamed glass or porcelain. At the end of the study plant growth index was greatest for stonecrop growing in shale, but there was no difference among the substrates for basil. However, plants of both basil and stonecrop accumulated the most total biomass when grown in shale. It is probable that water retention could be improved for both recycled crushed porcelain and foamed glass if more attention was paid to reducing particle size during processing. If so, then they may perform equal to heat expanded shale when incorporated into green roof substrates. In the case of porcelain, its use could divert some waste from landfills and greatly reduce the embodied energy required to construct a green roof. 
Key words: basil; extensive green roof; growing media; plant growth; recycled materials; sedum

\section{Introduction}

Green roofs are one of the tools that can be included in a strategy for mitigating environmental problems in urban areas by reducing stormwater runoff, conserving energy, mitigating the urban heat island, sequestrating carbon, providing habitat for wildlife, and providing space for urban food production (Getter et al., 2009; Oberndorfer et al., 2007;

Rowe, 2011; Whittinghill and Rowe, 2012). However, since these benefits are only realized once the roof has been constructed, one must also consider the embodied energy required to produce and transport the materials needed to construct the green roof to be truly sustainable. In North America the main component of green roof substrates often consists of light weight stable aggregates such as heat expanded slate, shale, or clay (Ampim et al., 2010). However, it requires a great deal of energy to produce these materials from mining the raw materials, processing, and shipping. For example, when a $6 \mathrm{~cm}$ deep Sedum roof in Michigan with a substrate consisting of heat-expanded slate as the main component was analyzed it was determined that $87 \%$ of the embodied energy required to construct the roof was accounted for in the production of the heat-expanded slate (Getter et al., 2009). The carbon released into the atmosphere in the production of the slate aggregate was greater than the potential maximum net carbon sequestration that this particular roof could sequester in its vegetation and substrate. It was estimated that the ratio of carbon stored to the amount of carbon released during construction would eventually favor storage after nine years because the building would require less energy to heat and cool. In a follow up study, Whittinghill et al. (2014) found that growing plants that could produce greater biomass could reduce the carbon payback period to less than three years. Of course, to do so required a deeper substrate and 
thus more embodied energy for construction, but the extra material was taken into consideration.

Similarly, Peri et al. (2012) evaluated how the individual components of a green roof contributed to the negative environmental impact of a green roof during the production, maintenance, and end of life disposal phases. Production of the growing substrate included pre-manufacturing (raw material extraction and production of the substrate); transportation of the finished substrate to the construction site, and manufacturing (installation of the finished substrate on the roof). Overall, they concluded that for the roof studied in Italy, the production phase resulted in the greatest strain on the environment in terms of abiotic depletion potential (extraction of natural resources), acidification potential (production of acidifying pollutants like sulfur containing gases), and global warming potential (release of carbon dioxide, nitrous oxide, and methane gas). Carbon dioxide and methane released during production accounted for $56 \%$ and $59 \%$ of the total emissions over the projected lifetime of the roof. Production of the substrate alone was the leading cause of acidification, euthrophication, and fresh water aquatic ecotoxicity potential. Likewise, Chenani et al. (2015) found that for a green roof in Chicago the components in the water retention, drainage, and substrate layers had the greatest negative environmental impact. The heat-expanded clay used in the substrate was a major contributor, even at rates as low as $10 \%$ by volume.

In all cases discussed above, it is evident that the use of alternative materials such as recycled wastes could lessen the impact of green roof construction on the environment. That is assuming that the properties of the substrate that support plant growth are not compromised so the roof can still provide the ecosystem services they are known for. Thus the growing substrate must still provide the chemical and physical properties necessary to support vegetation. It must be light weight to stay within a building's structural capacity, retain nutrients, and be porous enough to allow drainage while maintaining adequate water holding 
capacity. Drainage is very important, especially in the shallow substrate depths $(<20 \mathrm{~cm})$ found in extensive green roofs. According to German green roof standards published by the Forschungsgesellschaft Landschaftsentiwicklung Landschaftsbau (FLL, 2008), substrate mixtures for extensive green roofs containing organic matter should contain between 70 to $90 \%$ mineral content by volume. One of the key topics in green roof research is replacing these materials with recycled or locally available components to reduce the environmental impact of green roof construction.

Several previous studies have evaluated the use of recycled materials for use as the inorganic portion in green roof substrates. These include the use of slag (Williams et al, 2010), bottom ash from incinerators (Bates et al., 2015; Kanechi et al., 2014), fly ash in pellet form (Molineux et al. 2009), paper ash from recycled newspapers (Molineux, 2009; Molineux et al., 2015), crumb rubber or shredded tires (Pérez 2012; Solano et al., 2012; Steinfeld and Del Porto, 2008), aerated concrete (Bisceglie et al., 2014; Molineux et al., 2015), crushed demolition or construction waste (Bates et al., 2015; Mickovski et al., 2013), limestone quarry waste (Molineux, 2009; Molineux et al., 2015), crushed brick (Bates et al. 2015; Graceson et al., 2014a; Graceson et al., 2014b; Molineux et al. 2009; Molineux et al., 2015; Nagase et al., 2013; Young et al., 2014), crushed tile (Graceson et al., 2014a; Graceson et al., 2014b), crushed shells (Steinfeld and Del Porto, 2008), and crushed glass (Steinfeld and Del Porto, 2008).

However in this wide variety of research, other than Matlock and Rowe (2016), we could only find one other study that looked at the possibility of using crushed discarded porcelain as a green roof substrate (Steinfeld and Del Porto, 2008). Similarly, there is limited knowledge regarding recycled or foamed glass as a vegetation carrier in extensive green roofs (Klopp and Berghage, 2012). Neither of these studies were published in peer-reviewed 
scientific journals as the Steinfeld study was a preliminary report and the Klopp study was an undergraduate research project.

Both of these materials have the potential to improve the sustainability of green roof substrates. Porcelain can be obtained from demolition sites and diverted from being deposited in a landfill. It still needs to be processed (crushed) and transported, but does not need to be heat-expanded where $87 \%$ of the embodied energy was accounted for in the Getter et al (2009) study. The argument for foamed glass is not as straightforward as waste glass can often be recycled through normal channels. In addition, to produce the foamed product the glass must be ground and still heated to high temperatures. However, in the case of the foamed glass produced by Growstone, Inc. (Albuquerque, NM), the raw material glass is diverted from a landfill and the energy to process the final product is methane captured from the landfill.

In the above mentioned Matlock and Rowe (2016) study, a collection of nine herbaceous perennials and grasses were grown outdoors on green roof platforms for a period of two years. The main objective was to evaluate the effect of substrate type on total plant coverage regardless of species. Regardless of substrate type (heat-expanded shale, crushed porcelain, and foamed glass), nearly $100 \%$ coverage was achieved and maintained. This study was conducted simultaneously in the same substrates, but was different in study duration (12 weeks), environmental conditions (controlled environment greenhouse), and plant material (individual sedum and basil plants). By evaluating individual plants in this study, we were able to measure individual plant growth and biomass accumulation as well as plant stress via chlorophyll fluorescence. The outdoor Matlock and Rowe study was more representative of a real green roof installation, but from an experimental viewpoint, we could not control the environmental conditions. 
Therefore, the aim of this study was to evaluate two recycled materials, crushed

porcelain and foamed glass, to see if they were suitable alternative materials for use in green roof substrates. Their performance was compared to an industry standard substrate consisting of heat-expanded shale. Specific objectives including comparing physical and chemical properties of the three substrates and how they influenced substrate volumetric moisture content, plant growth, and plant stress responses as measured by chlorophyll fluorescence.

\section{Materials and Methods}

Two recycled materials (crushed porcelain and foamed glass) were tested for their suitability as green roof substrate components and were compared to heat-expanded shale which served as the control. The crushed porcelain (Michigan State University (MSU) Surplus Store and Recycling Center, East Lansing, MI) was obtained from on-campus demolition projects at MSU and included broken sinks, toilets, tiles, and dishes. The porcelain was processed using an aggregate crushing plant hired by MSU Landscape Services. The recycled foamed glass (Growstone GS-2 Soil Aerator, Growstone LLC, Albuquerque, NM) is a commercially available product often used for hydroponic applications. Recycled glass bottles are ground into a fine powder and the powdered glass is combined with foaming agents and kilned in a gas furnace using a blend of natural gas and landfill-sourced methane as a fuel source. The gas released by the foaming agent creates a network of micropores within the glass media. The raw product is then cracked, crushed, and blended. The heatexpanded shale or haydite was produced by the Hydraulic Press Brick Company in Indianapolis, IN. As raw shale was heated up to a temperature of $1204^{\circ} \mathrm{C}$ it expanded to several times its original volume, thus reducing the weight per unit volume.

The crushed porcelain and foamed glass substrates used in the study were prepared by mixing these materials with $20 \%$ municipal compost (Granger Waste Management Company, 
Lansing, MI). The heat-expanded shale substrate consisted of $24 \%$ haydite A $(0.07-2.38 \mathrm{~mm})$,

150

151

152

153

154

155 24\% haydite B (2.38-9.51 mm), 32\% 2NS sand (Renewed Earth, Kalamazoo, MI), and 20\%

of the given compost. Proportions were measured by volume according to German green roof industry guidelines (FLL, 2008). Each finished substrate was analyzed to determine granulometric distribution, bulk density, total porosity, water-holding capacity, saturated hydraulic conductivity, $\mathrm{pH}$, soluble salts, organic matter content, and cation exchange capacity (Pennsylvania State University Agricultural Analytical Services Laboratory, University Park, PA) (Table 1, Fig. 1).

Table 1. Substrate physical and chemical properties at initiation of the study.

\begin{tabular}{|c|c|c|c|c|c|}
\hline Characteristic & Unit & $\begin{array}{l}\text { Foamed } \\
\text { Glass }\end{array}$ & Porcelain & $\begin{array}{l}\text { Expanded } \\
\text { Shale }\end{array}$ & $\begin{array}{l}\text { FLL }^{1} \\
\text { Guidelines }\end{array}$ \\
\hline Bulk Density (dry weight basis) & $\mathrm{g} \cdot \mathrm{cm}^{-3}$ & 0.31 & 1.45 & 1.27 & - \\
\hline Bulk Density (at Max WHC) & $\mathrm{g} \cdot \mathrm{cm}^{-3}$ & 0.60 & 1.56 & 1.72 & - \\
\hline Total Pore Volume & $\% \mathrm{Vol}$ & 82.2 & 40.6 & 48.5 & - \\
\hline Maximum WHC & $\% \mathrm{Vol}$ & 29.8 & 12.9 & 20.3 & $20-65$ \\
\hline $\begin{array}{l}\text { Air-Filled Porosity } \\
\text { (at Max WHC) }\end{array}$ & $\% \mathrm{Vol}$ & 52.4 & 27.7 & 2.9 & $\geq 10$ \\
\hline Saturated Hydraulic Conductivity & $\mathrm{cm} \cdot \mathrm{s}^{-1}$ & $>0.711$ & $>0.723$ & 0.170 & $0.1-0.67$ \\
\hline $\mathrm{pH}$ & & 7.9 & 7.6 & 7.9 & $6.0-8.5$ \\
\hline Soluble Salts (water, 1:10, m:v) & $\operatorname{mmhos} \cdot \mathrm{cm}^{-1}$ & 0.41 & 0.13 & 0.22 & \\
\hline Soluble Salts (water, 1:10, m:v) & $\mathrm{g}(\mathrm{KCl}) / \mathrm{L}$ & 0.83 & 0.98 & 1.75 & $\leq 3.5$ \\
\hline Organic Matter Content & Mass \% & 11.8 & 2.1 & 3.2 & \\
\hline Organic Matter Content & $g \cdot \mathrm{L}^{-1}$ & 36.2 & 29.9 & 40.6 & $\leq 40$ \\
\hline Cation Exchange Capacity & $\mathrm{cmol} \cdot \mathrm{kg}_{-}{ }^{1}$ & 31.32 & 8.91 & 6.37 & none \\
\hline
\end{tabular}

Analysis performed by Pennsylvania State University Agricultural Analytical Services Laboratory, University Park, PA. WHC stands for Water Holding Capacity

${ }^{1}$ Forschungsgesellschaft Landschaftsentiwicklung Landschaftsbau (FLL). 2008. Guidelines for the Planning Execution and Upkeep of Green-Roof Sites. FLL Guidelines are for single course extensive green roofs. 


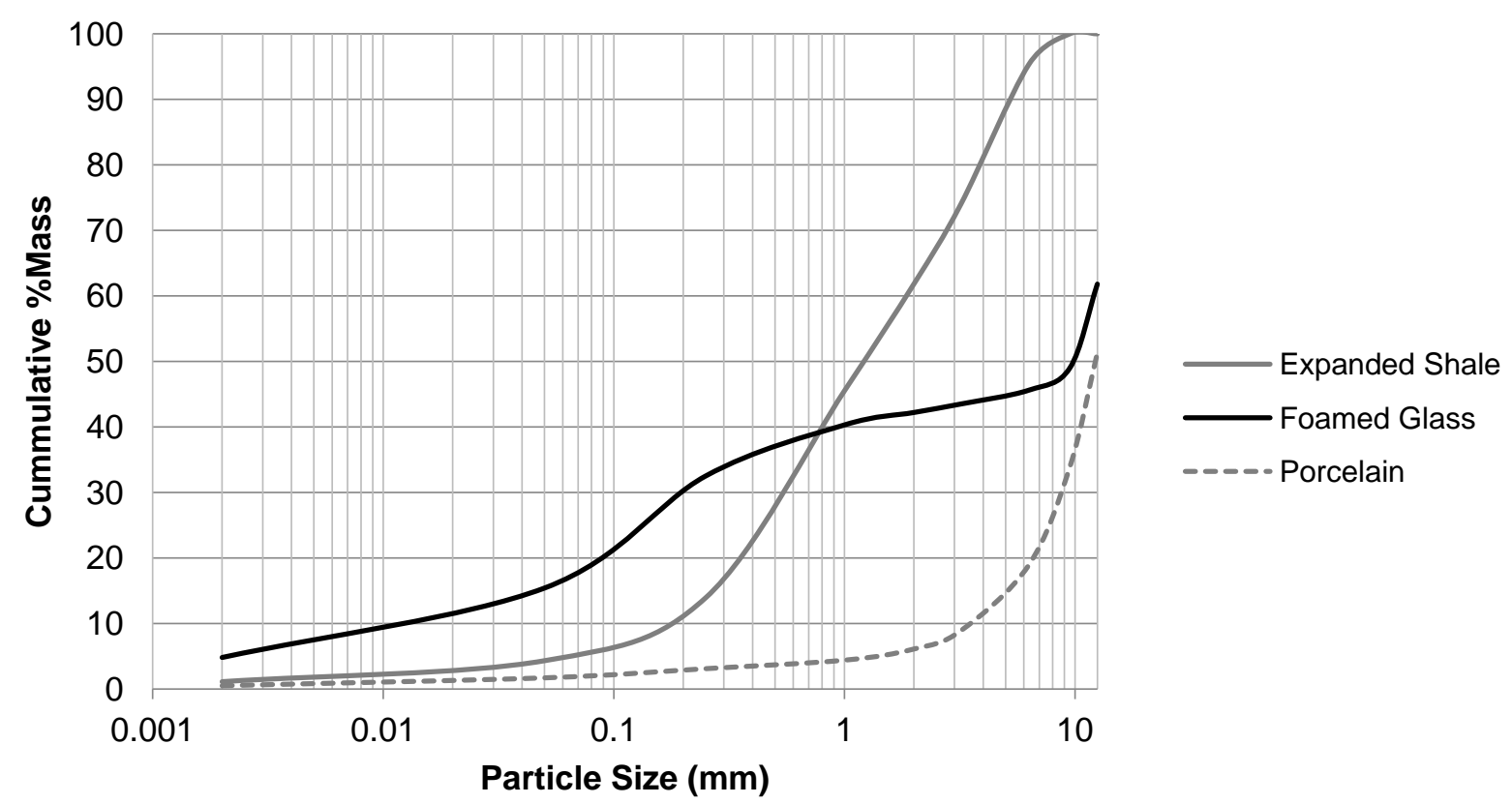

Figure 1. Substrate particle size distribution at initiation of study.

Substrates were screened using sieves with $0.002,0.05,0.25,1.0,2.0,3.2,6.3,9.5$, and 12.5 mm openings.

Two plant species were used in the study, Sedum album (White Stonecrop) and

Ocinum x citriodolum (Lemon Basil). Species were chosen because of their differences in

ecophysiological properties such as form of photosynthesis, growth habit, and morphology.

Stonecrop is a popular choice for extensive green roofing projects as a result of its tolerance

for drought (Durhman et al., 2006; Wolf and Lundholm, 2008) and Sedum album is a

relatively aggressive spreader (Monterusso et.al., 2005). Much of its drought tolerance can be

attributed to the fact that when subjected to drought, stonecrop can switch between $\mathrm{C} 3$ carbon

fixation and crassulacean acid metabolism (CAM) (Earnshaw et al. 1985; Bachereau et al.

(Kimball, 1983) and it is known to be a good indicator of water stress (Ekren et. al., 2012).

Furthermore, lemon basil is a good candidate for rooftop agriculture (Whittinghill et.al, 2013), 
and its economic value (essential oils) (Sifola and Barbieri, 2006) is largely affected by water stress (Khalid, 2006).

The study was conducted in the MSU Plant Science Greenhouses (East Lansing, MI) in plastic bulb crates measuring $60 \times 40 \mathrm{~cm}$. Each crate was filled to a depth of $10 \mathrm{~cm}$ as a single layer with one of three substrates and planted randomly with three plugs of both stonecrop and lemon basil on 22 November 2013. Crates were placed randomly on a greenhouse bench in a completely random design and each crate represented one replication. There were four replications of each substrate, each planted with three plugs of each species for a total of 36 plants of each species. Plugs had previously been propagated in 48-cell plug trays $(54 \mathrm{~cm} \times 28 \mathrm{~cm}$ x $6 \mathrm{~cm}$ ) on 24 October 2103 from either seed of lemon basil (Gurney's Seed and Nursery Co., Greendale, IN) or uniform $4 \mathrm{~cm}$ long stem cuttings of stonecrop taken from green roof platforms at the MSU Horticulture Teaching and Research Center (East Lansing, MI). During the study, plants were grown under natural light photoperiod and irradiance. Irradiance was measured at canopy level with a quantum sensor (model LI-250; LI-COR, Lincoln, NE) and ranged from $80 \mu \mathrm{mol} / \mathrm{s} / \mathrm{m}^{2}$ on a representative cloudy day to 950 $\mu \mathrm{mol} / \mathrm{s} / \mathrm{m}^{2}$ on a representative sunny day. Air temperature was controlled by a thermostat set at $21 \pm 1^{\circ} \mathrm{C}$. No fertilization or any pesticides were applied to the study plots. Crates were watered to field capacity by hand on the day of planting and supplemental irrigation was provided by hand once every other day until runoff. Although S. album does not require watering every day, this watering regimen was chosen because in a previous study conducted by the authors in the same greenhouse, the grass Schizachyrium scoparium and the herbaceous perennial Coreopsis lanceolata required watering every two days in order to survive (Durhman et al., 2006). It was assumed that lemon basil would have similar moisture requirements. 
Data collected included plant growth, plant stress, biomass accumulation, and substrate volumetric moisture content (VMC). With the exception of substrate moisture and biomass accumulation, measurements were recorded initially when the plugs were transplanted and then once every three weeks for the 12 week duration of the study. Plant growth was quantified by measuring plant height and width in two directions to form a growth index [(L x W x W)/3] (Monterusso et al., 2005; Rowe et al., 2006). Plant stress was quantified by measuring chlorophyll fluorescence (Fv/Fm) with a Hansatech Plant Efficiency Analyzer System (Hansatech Instruments, Ltd., Norfolk, U.K.). The ratio of variable fluorescence to maximum fluorescence $(\mathrm{Fv} / \mathrm{Fm})$ measures the maximum quantum efficiency of Photosystem II which is an indirect measure of plant stress (Durhman et al., 2006; Maxwell and Johnson, 2000; Ritchie, 2006). To obtain the measurements, leaf clips were attached randomly on leaves of each plant and dark-adapted for at least 20 minutes before measurements were performed. Standard error for this method was detected as \pm 0.03 . On two separate occasions during the study (day 51 during week 7, and day 82 during week 12), VMC for each substrate was measured to quantify the differences in initial moisture content and the change over time following watering. Measurements were recorded by taking readings immediately after irrigation and then at various intervals for a period of 16 hours during week 7 and at two hour intervals for a period of eight hours during week 12. VMC was monitored at three random points in each crate by inserting a theta probe (ML2x; Delta-T Devices, Ltd. Cambridge, U.K.) with $6.0-\mathrm{cm}$ rods into the substrate until they were completely buried. The theta probe instrument has a range of 0.0 to $1.0 \mathrm{~m} 3 \cdot \mathrm{m}-3$, with accuracy of $\pm 0.01 \mathrm{~m} 3 \cdot \mathrm{m}-3$ for values from 0.05 to $0.6 \mathrm{~m} 3 \cdot \mathrm{m}-3$. However, accuracy was likely lower for values below $0.05 \mathrm{~m} 3 \cdot \mathrm{m}-3$ (Delta-T Devices, Cambridge, U.K.). 
Biomass was measured by obtaining plant dry weights at the initiation of the study and at the end of 12 weeks. Initial dry weights were obtained from five representative samples of each plant species. Plants were removed from the substrate, separated into roots (belowground) and shoots (above-ground), washed, and then dried for $144 \mathrm{hr}$. at $60^{\circ} \mathrm{C}$. The same procedure were applied to all plants at the end of the study. Biomass accumulation was calculated as the difference between the mean initial and final dry weights.

\section{Statistical analysis.}

All data were checked for normality prior to analysis of variance by using the Kolmogorov-Smirnov test (Minitab, Inc., State College, PA). Although original means are reported, a log transformation was applied to root dry weight data of stonecrop and shoot and root dry weight data for lemon basil to stabilize the variance and normalize the data set.

Significant differences between treatments were determined by One-Way ANOVA test using Fisher's LSD comparison in Minitab ${ }^{\circledR}$ 16.2.2 (Minitab Inc., State College, PA).

\section{Results}

Substrate physical and chemical properties.

Substrate analysis provided a comparison of the alternative crushed porcelain and foamed glass substrates to a standard heat-expanded shale substrate that is commonly used in the green roof industry (Table 1, Fig. 1). With a few exceptions, all of the substrates met German FLL Guidelines for green roof substrates (FLL, 2008). Exceptions were maximum water holding capacity (WHC) of the porcelain substrate and air-filled porosity at maximum WHC for expanded shale, both of which were lower than recommended by FLL. In terms of particle size distribution, the expanded shale substrate approximated the range recommended by FLL guidelines, whereas the porcelain and foamed glass substrates contained a greater 
percentage of larger particles with nearly half of the mass consisting of particles that were larger than $12.5 \mathrm{~mm}$ (Fig. 1). Although the expanded shale contained the highest amount of organic matter on a weight basis, the foamed glass was much higher on a percentage basis than the other two substrates because of its low bulk density. Likewise, the foamed glass had a much higher CEC for the same reason.

\section{Substrate volumetric moisture content.}

Substrate VMC was generally greater in shale than in foamed glass or porcelain (Fig. 2). This was true immediately after watering and throughout the remainder of the day, regardless of sample date. Initial VMC was lower in foamed glass and porcelain due to their greater saturated hydraulic conductivity (Table 1) where a greater percentage of the applied water drained through the substrate. With the exception of porcelain on day 51 , further decreases in VMC over time due to evapotranspiration (ET) appeared to be relatively the same magnitude for all substrates.

After all treatments were irrigated on day 51, the decrease in VMC due to ET in shale was linear and fell from 0.28 to $0.20 \mathrm{~m} 3 \cdot \mathrm{m}-3$ during the $16 \mathrm{hr}$ period. Similarly, VMC in foamed glass was reduced from 0.20 to $0.09 \mathrm{~m} 3 \cdot \mathrm{m}-3$. In contrast, the initial VMC in the porcelain substrate was $0.25 \mathrm{~m} 3 \cdot \mathrm{m}-3$ and experienced a sharp decrease during the first three hours of observation. Afterwards, it experienced the same steady decrease as shale and foamed glass and eventually fell to $0.07 \mathrm{~m} 3 \cdot \mathrm{m}-3$ after 16 hours. When measurements were repeated on day 82 , similar results were observed. However, even though all substrates had a lower VMC when the first measurements were recorded, the shale displayed a more rapid decrease, and the large gap between shale and the other two substrates that was present during the first recording on day 51 had disappeared by hour 8 on day 82 . 


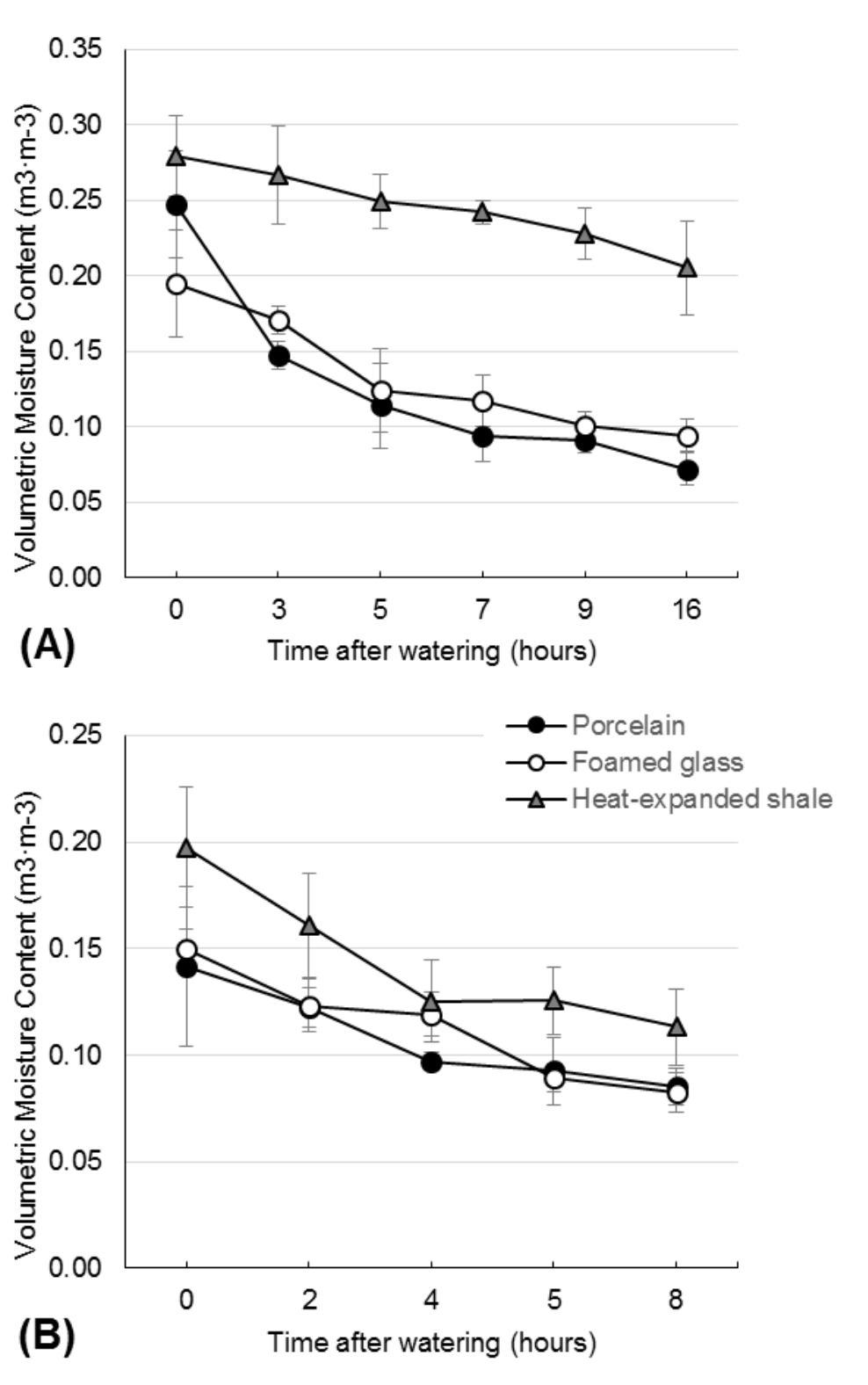

Figure 2. Mean volumetric moisture content (\%) of substrates in selected days. (A) 10 January 2014 (day 51, week 7) and (B) 7 February 2014 (day 82, week 12).

Plant growth index.

Regardless of substrate type, plants of stonecrop steadily increased in size over the 12 week period (Table 2). Differences in plant size among substrate treatments were not evident until week 6 and by week 9 plants of stonecrop growing in shale were larger than those growing in foamed glass and porcelain. Although plants of stonecrop growing in foamed glass 
were qualitatively larger than those in porcelain, they were not significantly different. By week 12, stonecrop growing in shale had experienced a nearly five-fold increase in size, those in foamed glass were almost four times as large, and those growing in porcelain had tripled in size. In contrast, the overall growth of basil leveled off after the third week regardless of substrate type. By week 3, plants of basil growing in shale were larger than those in foamed glass and continued to be so until week 12. Plants growing in foamed glass caught up by week 12 to the point where there were no differences in size of plants among the substrate treatments. Those in shale and porcelain were the same size throughout the study.

Table 2. Plant growth index over time of lemon basil and stonecrop grown in the foamed glass, crushed porcelain, and heat-expanded shale substrates.

\begin{tabular}{lccc}
\hline & Foamed glass & Porcelain & Heat-expanded shale \\
\hline Lemon basil (Ocinum x citriodolum) & & & \\
\hline Week 0 & $3.87 \mathrm{~A} \mathrm{~b}$ & $3.87 \mathrm{~A} \mathrm{c}$ & $3.87 \mathrm{~A} \mathrm{~b}$ \\
Week 3 & $6.44 \mathrm{~B} \mathrm{a}$ & $6.85 \mathrm{AB} \mathrm{b}$ & $7.99 \mathrm{~A} \mathrm{a}$ \\
Week 6 & $6.28 \mathrm{~B} \mathrm{a}$ & $6.93 \mathrm{AB} \mathrm{b}$ & $8.17 \mathrm{~A} \mathrm{a}$ \\
Week 9 & $6.03 \mathrm{~B} \mathrm{a}$ & $6.78 \mathrm{AB} \mathrm{b}$ & $7.75 \mathrm{~A} \mathrm{a}$ \\
Week 12 & $6.72 \mathrm{~A} \mathrm{a}$ & $8.00 \mathrm{~A} \mathrm{a}$ & $7.96 \mathrm{~A} \mathrm{a}$ \\
\hline Stonecrop (Sedum album) & & & \\
\hline Week 0 & $3.12 \mathrm{~A} \mathrm{~d}$ & $3.12 \mathrm{~A} \mathrm{~d}$ & $3.12 \mathrm{~A} \mathrm{c}$ \\
Week 3 & $5.54 \mathrm{~A} \mathrm{c}$ & $5.94 \mathrm{~A} \mathrm{c}$ & $6.32 \mathrm{~A} \mathrm{~b}$ \\
Week 6 & $6.64 \mathrm{AB} \mathrm{c}$ & $5.81 \mathrm{~B} \mathrm{c}$ & $8.29 \mathrm{~A} \mathrm{~b}$ \\
Week 9 & $9.51 \mathrm{~B} \mathrm{~b}$ & $8.31 \mathrm{~B} \mathrm{~b}$ & $12.36 \mathrm{~A} \mathrm{a}$ \\
Week 12 & $11.83 \mathrm{AB} \mathrm{a}$ & $10.06 \mathrm{~B} \mathrm{a}$ & $14.47 \mathrm{~A} \mathrm{a}$ \\
\hline
\end{tabular}

Plant growth index (PGI) was calculated for each species at each substrate type by averaging the three individual growth measurements including plant height and two-dimensional width of seedlings. Week $3=31$ Dec. 2013; Week 6 = 17 Jan. 2014; Week $9=7$ Feb. 2014; Week $12=27$ Feb. 2014.

Mean separation in rows and columns by least significant difference $(P=0.05)$. Uppercase letters in rows denote differences among substrates $(n=12)$. Lowercase letters in columns denote comparisons over time within individual substrate types and species $(n=12)$.

\section{Chlorophyll fluorescence.}

Stress levels of plants were detected by measuring chlorophyll florescence as the ratio of variable fluorescence to maximum fluorescence (Fv/Fm). Normal Fv/Fm values for healthy 
plants range from 0.700 to 0.800 and values below 0.600 are an indication that the plant may be experiencing stress (Ritchie, 2006).

At the time of transplant (week 0), all plants were very healthy with initial mean Fv/Fm values over 0.800 (Table 3). By week 3, mean Fv/Fm values had significantly decreased for both basil and stonecrop in all three substrates with the largest drop occurring in foamed glass. The decreases can be interpreted as plant stress due to transplanting or that the peat based horticultural substrate they were propagated in was more suitable for optimal growth and health. The fact that Fv/Fm values remained lower throughout the study suggests the latter. Even so, most of the values were still relatively high and would not indicate the plants were under stress. The exceptions all occurred during week 12 for basil growing in shale (0.587) and stonecrop growing in foamed glass (0.583) and porcelain (0.584).

Table 3. Chlorophyll fluorescence values (Fv/Fm) of lemon basil and stonecrop grown in the foamed glass, crushed porcelain, and heat-expanded shale substrates.

\begin{tabular}{llll}
\hline & Foamed glass & Porcelain & Heat-expanded shale \\
\hline Lemon basil (Ocinum x citriodolum) & & \\
\hline Week 0 & $0.801 \mathrm{~A} \mathrm{a}$ & $0.801 \mathrm{~A} \mathrm{a}$ & $0.801 \mathrm{~A} \mathrm{a}$ \\
Week 3 & $0.618 \mathrm{~B} \mathrm{~b}$ & $0.721 \mathrm{~A} \mathrm{~b}$ & $0.667 \mathrm{AB} \mathrm{b}$ \\
Week 6 & $0.648 \mathrm{~A} \mathrm{~b}$ & $0.640 \mathrm{~A} \mathrm{c}$ & $0.663 \mathrm{~A} \mathrm{~b}$ \\
Week 9 & $0.603 \mathrm{~B} \mathrm{~b}$ & $0.696 \mathrm{~A} \mathrm{~b}$ & $0.618 \mathrm{~B} \mathrm{bc}$ \\
Week 12 & $0.645 \mathrm{AB} \mathrm{b}$ & $0.697 \mathrm{~A} \mathrm{~b}$ & $0.587 \mathrm{~B} \mathrm{c}$ \\
\hline Stonecrop (Sedum album) & & & \\
\hline Week 0 & $0.805 \mathrm{~A} \mathrm{a}$ & $0.805 \mathrm{~A} \mathrm{a}$ & $0.805 \mathrm{~A} \mathrm{a}$ \\
Week 3 & $0.719 \mathrm{~A} \mathrm{~b}$ & $0.739 \mathrm{~A} \mathrm{~b}$ & $0.729 \mathrm{~A} \mathrm{~b}$ \\
Week 6 & $0.723 \mathrm{~A} \mathrm{~b}$ & $0.725 \mathrm{~A} \mathrm{~b}$ & $0.707 \mathrm{~A} \mathrm{~b}$ \\
Week 9 & $0.698 \mathrm{~B} \mathrm{~b}$ & $0.740 \mathrm{~A} \mathrm{~b}$ & $0.729 \mathrm{AB} \mathrm{b}$ \\
Week 12 & $0.583 \mathrm{~B} \mathrm{c}$ & $0.584 \mathrm{~B} \mathrm{c}$ & $0.680 \mathrm{~A} \mathrm{~b}$ \\
\hline
\end{tabular}

Week 3 = 31 Dec. 2013; Week 6 = 17 Jan. 2014; Week 9 = 7 Feb. 2014; Week 12 = 27 Feb. 2014.

Mean separation in rows and columns by least significant difference $(\mathrm{P}=0.05)$. Uppercase letters in rows denote differences among substrates $(n=12)$. Lowercase letters in columns denote comparisons over time within individual substrate types and species $(n=12)$. 

statistically equal to or greater than those growing in foamed glass or shale. Based on Fv/Fm values, basil plants growing in foamed glass during weeks 3 and 9 and in shale at weeks 9 and

334 relatively the same among substrates. However, stonecrop was more stressed in foamed glass by week 9 than those growing in porcelain and by the end of the study at week 12, stonecrop growing in foamed glass and porcelain had lower Fv/Fm values than stonecrop in shale.

\section{Biomass accumulation.}

Increases in plant biomass at the end of the study generally mirrored the results for plant growth index. After the initial planting, plants of both basil and stonecrop accumulated the most total biomass when grown in shale (Table 4). Plants of basil added almost three times as much biomass growing in shale compared to foamed glass. Shale positively influenced biomass production of basil seedlings as initial mean total dry weight experienced a ten-fold increase from $0.03 \mathrm{mg}$ to $0.32 \mathrm{mg}$ over the 12 weeks of the study. In contrast, basil in foamed glass only increased $0.09 \mathrm{mg}$. As expected, similar results were found when total biomass of basil was divided into roots and shoots (Table 4). The differences were not as large for stonecrop, but those plants in shale still added more shoot biomass than those growing in porcelain and foamed glass. There was little difference in root dry mass accumulation for stonecrop, although foamed glass again resulted in the lowest biomass accumulation. (1) 
Table 4. Shoot and root dry weight biomass accumulation ( $\mathrm{g}$ ) for lemon basil and stonecrop grown in the foamed glass, crushed porcelain, and heat-expanded shale substrates.

\begin{tabular}{|c|c|c|c|c|}
\hline & Root & Shoot & Total & $\begin{array}{l}\text { Root:shoot } \\
\text { ratio }\end{array}$ \\
\hline \multicolumn{5}{|c|}{ Lemon basil (Ocinum $\mathrm{x}$ citriodolum) } \\
\hline Heat-expanded shale & $0.10 \mathrm{a}$ & $0.22 \mathrm{a}$ & $0.32 \mathrm{a}$ & $0.022 \mathrm{~b}$ \\
\hline Porcelain & $0.05 \mathrm{~b}$ & $0.16 \mathrm{ab}$ & $0.21 \mathrm{~b}$ & $0.313 \mathrm{a}$ \\
\hline Foamed glass & $0.03 \mathrm{c}$ & $0.09 \mathrm{~b}$ & $0.12 \mathrm{c}$ & $0.333 \mathrm{a}$ \\
\hline \multicolumn{5}{|c|}{ Stonecrop (Sedum album) } \\
\hline Heat-expanded shale & $0.18 \mathrm{a}$ & $0.87 \mathrm{a}$ & $1.05 \mathrm{a}$ & $0.206 \mathrm{c}$ \\
\hline Porcelain & $0.18 \mathrm{a}$ & $0.47 \mathrm{~b}$ & $0.65 \mathrm{~b}$ & $0.383 \mathrm{a}$ \\
\hline Foamed glass & $0.15 \mathrm{~b}$ & $0.52 \mathrm{~b}$ & $0.67 \mathrm{~b}$ & $0.288 \mathrm{~b}$ \\
\hline
\end{tabular}

Initial dry weights $(\mathrm{g})$ at time of planting for lemon basil (root $=0.026$, shoot $=0.005$, total $=$ 0.031 ) and stonecrop (root $=0.080$, shoot $=0.036$, and total $=0.116)$. Accumulation $=$ Final dry weight - Initial dry weight.

Mean separation in columns by least significant difference $(P=0.05)$

\section{Discussion}

When interpreting substrate physical and chemical properties in Table 1, one must also consider how the bulk densities of each substrate influenced these values. For example, CEC for foamed glass is much higher than porcelain or expanded shale on a weight basis, but since the bulk density of porcelain and expanded shale is much greater than foamed glass, the values are relatively equal when adjusted for volume. The same logic applies to organic matter content. Also, both the total pore volume and air-filled porosity at maximum WHC of the foamed glass substrate are substantially higher than the other two substrates. However, due to the production process utilized to make this material some of this air space may be isolated cells within the aggregate that are not accessible to water or growing roots.

Regardless, the porcelain and foamed glass substrates both contained a greater percentage of large particles compared to the expanded shale. This resulted in much higher saturated hydraulic conductivity and air-filled porosity at maximum WHC. As stated by Hallett and Bengough (2013), there is an inverse relationship between the magnitude of matric potential (or suction) and pore radius, resulting in the gradual drainage of pores from 
largest to smallest as suction increases and the soil dries. Furthermore, capillary action would be greatly reduced because of the larger particle size (Wanphen and Nagano, 2009). Thus the large particle sizes of the porcelain and foamed glass substrates resulted in faster drainage than was likely less than ideal for the species tested.

Mean VMC turned out as expected with greater moisture present in the shale which in turn resulted in greater growth as seen in other studies (Wolf and Lundholm, 2008). Limited moisture in the foamed glass resulted in lower biomass accumulation and relatively higher stress levels for the plants. Growth and biomass accumulation are a reflection of plant health and growth by the end of the study generally reflected this. However, there were differences among plant species. Larger differences in biomass accumulation among the substrates for basil compared to stonecrop suggest that stonecrop was more adaptable to the coarser foamed glass and porcelain substrates. The low Fv/Fm values for basil growing in shale towards the end of the study could be attributed to a higher water demand because of the greater biomass that had accumulated as well as the morphological adaptations associated with sedum. CAM plants such as stonecrop are more capable of adapting to adverse environmental conditions such as drought on green roofs than C3 plants such as basil (Rowe et. al., 2012). Thus, plant growth of stonecrop was greater than basil due to their physiological advantage.

When biomass accumulation was recorded separately for roots and shoots, the root:shoot ratios for both basil and stonecrop were higher for those plants growing in porcelain or foamed glass (Table 4). When water is limiting in the root zone, plants partition greater growth to the roots relative to shoots which can be explained considering the hydrotropic response of root systems (Takahashi, 1997). This was previously found to be true for Sedum floriferum where root growth was favored when plants were subjected to water stress (Rowe et al., 2014). In this study, the drier foamed glass and porcelain substrates may also explain why stonecrop and basil both allocated more biomass to the roots as seen in the 
root:shoot ratios (Table 4). Similarly, Young et.al. (2014) reported that plant growth was significantly decreased when brick particle size was increased in a green roof substrate. The large brick substrates had a lower water holding capacity than small brick (-35\%), which led to decreased shoot growth (-17\%) and increased root:shoot ratio (+16\%). In our study, differences in root:shoot allocation occurred rather quickly even though the plants were subject to a regular watering regimen. These results further emphasize the relatively fast drainage and dry down of the courser substrates as shown in Figure 2.

In this study the shale substrate generally outperformed the foamed glass and porcelain substrates. However, in a concurrent study where the exact same substrates were used outdoors on green roof platforms, all three substrates were found to be equivalent in terms of plant coverage (Matlock and Rowe, 2016). So why the conflicting results? There could be several explanations.

First, the current study was only conducted for a period of 12 weeks, whereas the Matlock and Rowe study extended through two growing seasons. The stonecrop and basil plants in the greenhouse were never crowded by other plants and never achieved $100 \%$ coverage. In the outdoor study the plants had a chance to become mature and reached $100 \%$ coverage where competition for space, sunlight, and water became factors. Species included Alllium cernuum, Allium senescens, Coreopsis lanceolata, Koeleria macrantha, Monarda punctata, Sedum acre, Sedum album, Sedum kamtschaticum, and Tradescantia ohiensis. Although there were differences in coverage among species, full plant coverage was achieved in all three substrates. For example, both Allium spp. did well in shale, but A. senescens completely disappeared in foamed glass. In contrast, $K$. macrantha and $T$. ohiensis performed best in foamed glass. Among the Sedum spp., there was not much difference among the substrates although $S$. acre performed best in porcelain. 

Rowe study represented three life-form groups that were interplanted. Regardless of how an individual species performed, there were enough different life forms or species present that full coverage was achieved. In an earlier study comparing combinations of life-form groups, Lundholm et al. (2010) found that a combination of succulents, tall forbs and grasses outperformed most of the monocultures in their study. They concluded that incorporating varied growth forms increases the diversity of green roofs and potentially improves the resilience and long term performance of green roof systems (Lundholm et al., 2010; Heim and Lundholm, 2014). In our study the stonecrop and basil were grown as monocultures.

Third, the perennials and grasses in the Matlock and Rowe study likely had larger root systems because they were older and had to withstand periods of drought outdoors. Because they had a much longer period of time to grow these plant were more acclimated to drought conditions as their roots reached the moist favorable growing environment near the bottom. Root systems of the outdoor plants penetrated to the lower levels of the substrate where the smaller aggregate particles and the organic matter tended to settle. In contrast, plants in the greenhouse were watered on a regular schedule so the plants were theoretically never under drought stress. Therefore, they did not allocate as much biomass to the root systems. Fourth, plants growing outdoors in the porcelain and foamed glass substrates could have possibly overcome at least part of the lower water holding capacity of those substrates because of differences in substrate temperatures (Matlock and Rowe, 2016). During the summer, daytime subsurface temperatures in the porcelain and foamed glass outside were generally lower than the expanded shale. The green roofs in the outdoor study were exposed to direct sunlight during the summer months, whereas the greenhouse experiment was conducted during the winter. Although substrate temperatures were not measured in this 
greenhouse experiment, there were likely not many differences. Actual green roof performance outdoors seems to be more credible than what occurred in a greenhouse. In a previous study that evaluated foamed glass for use on green roofs, Klopp and Berghage (2012) blended fine and medium textured foamed glass with a commercial peat based greenhouse growing media in a 1:1:1 ratio which were then planted with a variety of sedum species. They concluded that the foamed glass based media was suitable for green roofs as it supported plant growth, was very light weight, and held adequate moisture and air. At field capacity, they reported a WHC of about $30 \%$ and air-filled porosity of $50 \%$ for their substrate, which was almost identical to the foamed glass substrate used in this study, $52.4 \%$ and $29.8 \%$, respectively.

A major advantage of foamed glass is that it is very lightweight as its bulk density is a fourth that of expanded shale. This property is significant in terms of roof structural weight capacity as well as for shipping costs. Lighter substrates expand the number of roofs capable of supporting a green roof and/or allows for greater substrate depths. In addition, deeper substrate depths enable designers to utilize an expanded plant palette due to greater water retention (Rowe et al., 2012).

In the only other study we could find that evaluated porcelain for use on green roofs, Steinfeld and Del Porto (2008) reported that although it was visually appealing, tumbled porcelain with an average size of $0.63 \mathrm{~cm}$ was not suitable for use as a green roof substrate. However, their substrate consisted of $100 \%$ porcelain and was not amended with any organic matter or other materials to improve the growth environment. This would not be a normal green roof substrate so it is difficult to compare. Maximum WHC of their substrate was only $3.3 \%$ and air-filled porosity at WHC was $57.7 \%$. In the present study, these values were $12.9 \%$ and $27.7 \%$, respectively. 

demolition projects and was processed using an aggregate crushing plant. Due to limitations of this equipment the porcelain was crushed to produce a particle size distribution approximating the Michigan 21AA standard for crushed concrete. This resulted in larger particle sizes than would be acceptable to satisfy FLL requirements for green roof substrates. In this case, approximately $50 \%$ of the porcelain mass consisted of particles greater than 12.5 mm (Fig. 1). If the crushing process were to be fine-tuned to produce smaller particle sizes then WHC could be increased while SHC was decreased. Both would likely improve plant performance. The same argument could be made for foamed glass to improve its performance. Regarding sustainability, both of these materials have the potential to improve the sustainability of green roof substrates. Waste can be diverted from landfills and if sourced locally, the energy required for transportation can be reduced. In the case of crushed porcelain, there is no longer a need to heat-expand the shale, slate, or clay aggregates, a process that accounted for $87 \%$ of the embodied energy in the getter et al. (2009) study. The foamed glass still requires substantial energy for processing, but in the case of the foamed there service lives can be extended beyond their original purpose. green roof substrate consisting of heat-expanded shale when compared to recycled materials such as crushed porcelain and foamed glass. However, because the substrates consisting of 
the number of large particles could possibly improve water retention and plant growth. This is especially true for the crushed porcelain that was crushed with the equipment available rather than to FLL standards. In addition, in the case of porcelain its use could greatly reduce the embodied energy required to construct a green roof and divert waste from landfills. Further research is advisable to determine the long term effects of these substrates on green roof performance.

\section{Acknowledgements}

This project was supported by the USDA National Institute of Food and Agriculture, the Michigan Department of Agriculture and Natural Resources, and by AgBioResearch at Michigan State University. Additional funding was provided by TUBITAK (The Scientific and Technical Research Council of Turkey) 2219 International Postdoctoral Research Scholarship Programme; Renewed Earth, Kalamazoo, MI; Growstone, LLC, Albuquerque, NM; MSU Landscape Services; MSU Recycling Center; Granger Waste Management Company, Lansing, MI; Ford Motor Company, Dearborn, MI; ChristenDETROIT Roofing Contractors, Detroit, MI; and XeroFlor America, Durham, NC. Mert Eksi was a visiting scholar at MSU during 2013-14. The authors also acknowledge Hamidah Ahmad's assistance in data collection.

\section{References}

Ampim, P., Sloan, J., Cabrera, R., Harp, D., Jaber, F., 2010. Green roof growing substrates: types, ingredients, composition, and properties. Journal of Environmental Horticulture 28(4), 244-252. 
Bachereau, F., Marigo, G., Asta, J., 1998. Effect of solar radiation (UV and visible) at high altitude on CAM-cycling and phenolic compound biosynthesis in Sedum album. Physiologia Plantarum 104(2), 203-210.

Bates, A., Sadler, J., Greswell, R., Mackay, R., 2015. Effects of recycled aggregate growth substrate on green roof vegetation development: A six year experiment. Landscape and Urban Planning 135, 22-31.

Bisceglie, F., Gigante, E., Bergonzoni, M., 2014. Utilization of waste autoclaved aerated concrete as lighting material in the structure of a green roof. Construction and Building Materials 69, 351-361.

Chenani, S.B., Lehvävirta, S., Häkkinen, T., 2015. Life cycle assessment of layers of green roofs. Journal of Cleaner Production 90, 153-162.

Durhman, A. K., Rowe, D. B., Rugh, C. L., 2006. Effect of watering regimen on chlorophyll fluorescence and growth of selected green roof plant taxa. HortScience, 41(7), 1623-1628.

Earnshaw, M. J., Carver, K.A., Lee, J.A., 1985. Changes in leaf water potential in Sempervivum montanum and Sedum album in response to water availability in the field. Oecologia. 67, 486-492.

Ekren, S., Sönmez, Ç., Özçakal, E., Kurttaş, Y.S.K., Bayram, E., Gürgülü, H., 2012. The effect of different irrigation water levels on yield and quality characteristics of purple basil (Ocimum basilicum L.). Agricultural Water Management 109, 155-161. 
549 Forschungsgesellschaft Landschaftsentwicklung Landschaftsbau (FLL) (Society of Landscape

550 Development and Landscape Design), 2008. Guidelines for the planning, construction, and

551

552

553

554

555

556

557

558

559

560

561

562

563

564

565

566

567

568

569

570

571

572

maintenance of green-roof sites. FLL, Bonn, Germany.

Getter, K.L., Rowe, D.B., Robertson, G.P., Cregg, B.M., Andresen, J.A., 2009. Carbon sequestration potential of extensive green roofs. Environmental Science and Technology 43(19), 7564-7570.

Graceson, A., Hare, M., Hall, N. Monaghan, J., 2014a. Use of inorganic substrates and composted green waste in growing media for green roofs. Biosystems Engineering 124, 1-7.

Graceson, A., Monaghan, J., Hall, N., Hare, M. 2014b. Plant growth responses to different growing media for green roofs. Ecological Engineering 69, 196-200.

Hallett, P.D., Bengough, A.G., 2013. Managing the soil physical environment for plants. In:

Gregory, P., Nortcliff, S. (Eds.), Soil conditions and plant growth, Blackwell Publishing Ltd., U.K., pp. 269-322.

Heim, A., Lundholm, J., 2014. Species interactions in green roof vegetation suggest complementary planting mixtures. Landscape and Urban Planning 130, 125-133.

Kanechi, M., Fujiwara, S., Shintani, N., Suzuki, T., Uno. Y., 2014. Performance of herbaceous Evolvulus pilosus on urban green roof in relation to substrate and irrigation.

Urban Forestry and Urban Greening 13, 184-191. 
574 Khalid, K.A., 2006. Influence of water stress on growth, essential oil, and chemical 575 composition of herbs (Ocimum sp.). International Agrophysics 20, 289-296.

576

577 Kimball, B.A. 1983. Carbon dioxide and agricultural yield: an assemblage and analysis of 430 578 prior observations. Agronomy Journal 75(5), 779-788.

579

580

Klopp, T., Berghage, R., 2012. The use of Growstone recycled glass material as a greenroof

581

media, Technical Bulletin, Pennsylvania State University, Department of Horticulture, Center for Green Roof Research.

583

584

Lundholm, J., MacIvor, J.S., MacDougall, Z., Ranalli, M.A., 2010. Plant form mixtures and 585 monocultures on extensive green roofs. Proceedings of $8^{\text {th }}$ Annual Green Roof and Wall Conference, Cities Alive, Vancouver, B.C.

587

Matlock, J.M., Rowe, D.B., 2016. The suitability of crushed porcelain and foamed glass as 589 alternatives to heat-expanded shale in green roof substrates: an assessment of plant growth, 590 substrate moisture, and thermal regulation. Ecological Engineering 94, 244-254

591 (http://dx.doi.org/10.1016/j.ecoleng.2016.05.044).

Maxwell, K., Johnson, G. N., 2000. Chlorophyll fluorescence-a practical guide. Journal of Experimental Botany 51(345), 659-668. 
603

604

605

606

607

608

609

610

611

612

613

614

615

616

617

618

619

Mickovski, S.B., Buss, K., McKenzie, B.M., Sökmener, B., 2013. Laboratory study on the potential use of recycled inert construction waste material in the substrate mix for extensive green roofs. Ecological Engineering 61P, 706-714.

Molineux, C. J., Fentiman, C. H., Gange, A. C., 2009. Characterising alternative recycled waste materials for use as green roof growing media in the UK. Ecological Engineering, 35(10), 1507-1513.

Molineux, C.J., Gange, A.C., Connop, S.P., Newport, D.J., 2015. Using recycled aggregates in green roof substrates for plant diversity. Ecological Engineering 82, 596-604.

Monterusso, M. A., Rowe, D. B., Rugh, C. L., 2005. Establishment and persistence of Sedum spp. and native taxa for green roof applications. HortScience, 40(2), 391-396.

Nagase, A., Dunnett, N., Choi, M. S., 2013. Investigation of weed phenology in an establishing semi-extensive green roof. Ecological Engineering, 58, 156-164.

Oberndorfer, E., Lundholm, J., Bass, B., Connelly, M., Coffman, R., Doshi, H., Dunnett, N., Gaffin, S., Köhler, M., Lui, K., Rowe, B., 2007. Green roofs as urban ecosystems: ecological structures, functions, and services. BioScience 57(10), 823-833.

Pérez, G., Vila, A., Rincón, L., Solé, C., Cabeza, L., 2012. Use of rubber crumbs as drainage layer in green roofs as potential energy improvement material. Applied Energy 97, 347-354. 
623

624

627

628

629

630

631

632

633

634

635

636

637

638

639

640

641

642

643

644

Peri, G., Traverso, M., Finkbeiner, M., Rizzo, G., 2012. Embedding “substrate” in

environmental assessment of green roofs life cycle: evidences from an application to the whole chain in a Mediterranean site. Journal of Cleaner Production 35, 274-287.

Ritchie, G., 2006. Chlorophyll fluorescence: What is it and what do the numbers mean? p.

34-43. In: USDA Forest Service Proceedings RMRSP-43. U.S. Department of Agriculture, Forest Service, Rocky Mountain Research Station, Fort Collins, CO.

Rowe, D. B., Monterusso, M. A., Rugh, C. L., 2006. Assessment of heat-expanded slate and fertility requirements in green roof substrates. HortTechnology, 16(3), 471-477.

Rowe, D.B. 2011. Green roofs as a means of pollution abatement. Environmental Pollution 159(8-9), 2100-2110.

Rowe, D.B., Getter, K.L., Durhman, A.K., 2012. Effect of green roof media depth on Crassulacean plant succession over seven years. Landscape and Urban Planning 104(3-4), 310-319.

Rowe, D.B., Kolp, M.R., Greer, S.E., Getter, K.L., 2014. Comparison of irrigation efficiency and plant health of overhead, drip, and sub-irrigation for extensive green roofs. Ecological Engineering 64, 306-313.

Sifola, M. I., Barbieri, G., 2006. Growth, yield and essential oil content of three cultivars of basil grown under different levels of nitrogen in the field. Scientia Horticulturae 108, 408413. 
646 Solano, L., Ristvey, A.G., Lea-Cox, J.D. Cohan, S.M., 2012. Sequestering zinc from recycled

647 crumb rubber in extensive green roof media. Ecological Engineering 47, 284-290.

648

649 Steinfeld, C., Del Porto, D., 2008. Green roof alternative substrate pilot study, preliminary 650 report, University of Massachusetts, Dartmouth.

651

652

Takahashi, H., 1997. Hydrotropism: the current state of our knowledge. Journal of Plant

653

Research 110, 163-169.

654

655

Wanphen, S., Nagano, K., 2009. Experimental study of the performance of porous materials

656

to moderate the roof surface temperature by its evaporative cooling effect. Building and

657

Environment 44(2), 338-351.

658

659

660

Whittinghill, L.J., Rowe, D.B., 2012. The role of green roof technology in urban agriculture.

Renewable Agriculture and Food Systems 27(4), 314-322.

661

662

Whittinghill, L.J., Rowe. D.B., Cregg, B.M., 2013. Evaluation of vegetable production on

663

extensive green roofs. Agroecology and Sustainable Food Systems 37, 465-484.

664

665 Whittinghill, L.J., Rowe, D.B., Cregg, B.M., Schutzki, R., 2014. Quantifying carbon

666 sequestration of various green roof and ornamental landscape systems. Landscape and Urban 667 Planning 123, 41-48.

668 
669 Williams, N. S., Rayner, J. P., Raynor, K. J., 2010. Green roofs for a wide brown land:

670 Opportunities and barriers for rooftop greening in Australia. Urban Forestry and Urban 671 Greening, 9(3), 245-251.

672

673 Wolf, D., Lundholm, J. T., 2008. Water uptake in green roof microcosms: Effects of plant 674 species and water availability. Ecological Engineering, 33(2), 179-186.

675

676 Young, T., Cameron, D. D., Sorrill, J., Edwards, T., Phoenix, G. K., 2014. Importance of

677 different components of green roof substrate on plant growth and physiological performance.

678 Urban Forestry and Urban Greening 13, 507-516.

679 